R E V I S T A

DO I N S T I T U T O $\mathrm{DE}$

M E D I C I N A T R O P I C A L DE S ÃO PAULO JOURNAL OF THE SÃO PAULO INSTITUTE OF TROPICAL MEDICINE
ERRATUM

http://doi.org/10.1590/S1678-9946202163040err

\section{Deep sequencing applied to the analysis of viromes in patients with beta-thalassemia}

Rev Inst Med Trop Sao Paulo. 2021;63:e40

http://dx.doi.org/10.1590/s1678-9946202163040

Page 1, where it reads:

Rafael Bezerra dos Santos

Should be read:

Rafael dos Santos Bezerra 